Research

Open Access

\title{
Comparison of cardiac, hepatic, and renal effects of arginine vasopressin and noradrenaline during porcine fecal peritonitis: a randomized controlled trial
}

\author{
Florian Simon ${ }^{1,2^{\star}}$, Ricardo Giudici ${ }^{1,3^{*}}$, Angelika Scheuerle ${ }^{4}$, Michael Gröger ${ }^{1}$, Pierre Asfar ${ }^{5}$, \\ Josef A Vogt ${ }^{1}$, Ulrich Wachter ${ }^{1}$, Franz Ploner ${ }^{1,6}$, Michael Georgieff', Peter Möller ${ }^{4}$, \\ Régent Laporte ${ }^{7}$, Peter Radermacher ${ }^{1}$, Enrico Calzia ${ }^{1}$ and Balázs Hauser ${ }^{1,8}$
}

\author{
1Sektion Anästhesiologische Pathophysiologie und Verfahrensentwicklung, Klinik für Anästhesiologie, Universitätsklinikum, Steinhövelstrasse 9, \\ 89075 Ulm, Germany \\ ${ }^{2}$ Abteilung Thorax- und Gefäßchirurgie, Universitätsklinikum, Steinhövelstrasse 9, 89075 Ulm, Germany \\ ${ }^{3}$ Instituto di Anestesiologia e Rianimazione dell'Università degli Studi di Milano, Azienda Ospedaliera, Polo Universitario San Paolo, Via di Rudin 8, \\ 20142 Milan, Italy \\ ${ }^{4}$ Abteilung Pathologie, Universitätsklinikum, Albert-Einstein-Allee 11, 89081 Ulm, Germany \\ 5Laboratoire HIFIH, UPRES-EA 3859, IFR 132, Universitè d'Angers, Département de Réanimation Médicale et de Médecine Hyperbare, Centre \\ Hospitalo- Universitaire, 4, rue Larrey, 49933 Angers cedex 9, France \\ ${ }^{6}$ Abteilung für Anästhesiologie und Schmerztherapie, Landeskrankenhaus Sterzing, Margarethenstraße 24, 39049 Sterzing, Italy \\ ${ }^{7}$ Ferring Research Institute Inc., 3550 General Atomics Court, Bldg 2 Room 444, San Diego, CA 92121, USA \\ ${ }^{8}$ Semmelweis Egyetem, Aneszteziológiai és Intenzív Terápiás Klinika, Kútvölgyi út 4., 1125 Budapest, Hungary \\ * Contributed equally
}

Corresponding author: Peter Radermacher, peter.radermacher@uni-ulm.de

Received: 7 May 2009 Revisions requested: 11 Jun 2009 Revisions received: 18 Jun 2009 Accepted: 10 Jul 2009 Published: 10 Jul 2009

Critical Care 2009, 13:R113 (doi:10.1186/cc7959)

This article is online at: http://ccforum.com/content/13/4/R113

(c) 2009 Simon et al.; licensee BioMed Central Ltd.

This is an open access article distributed under the terms of the Creative Commons Attribution License (http://creativecommons.org/licenses/by/2.0), which permits unrestricted use, distribution, and reproduction in any medium, provided the original work is properly cited.

\begin{abstract}
Introduction Infusing arginine vasopressin (AVP) in vasodilatory shock usually decreases cardiac output and thus systemic oxygen transport. It is still a matter of debate whether this vasoconstriction impedes visceral organ blood flow and thereby causes organ dysfunction and injury. Therefore, we tested the hypothesis whether low-dose AVP is safe with respect to liver, kidney, and heart function and organ injury during resuscitated septic shock.
\end{abstract}

Methods After intraperitoneal inoculation of autologous feces, 24 anesthetized, mechanically ventilated, and instrumented pigs were randomly assigned to noradrenaline alone (increments of $0.05 \mu \mathrm{g} / \mathrm{kg} / \mathrm{min}$ until maximal heart rate of 160 beats $/ \mathrm{min} ; \mathrm{n}=$ 12) or AVP ( 1 to $5 \mathrm{ng} / \mathrm{kg} / \mathrm{min}$; supplemented by noradrenaline if the maximal AVP dosage failed to maintain mean blood pressure; $n=12$ ) to treat sepsis-associated hypotension. Parameters of systemic and regional hemodynamics (ultrasound flow probes on the portal vein and hepatic artery), oxygen transport, metabolism (endogenous glucose production and whole body glucose oxidation derived from blood glucose isotope and expiratory ${ }^{13} \mathrm{CO}_{2} /{ }^{12} \mathrm{CO}_{2}$ enrichment during $1,2,3,4,5,6-{ }^{13} \mathrm{C}_{6}$-glucose infusion), visceral organ function (blood transaminase activities, bilirubin and creatinine concentrations, creatinine clearance, fractional $\mathrm{Na}^{+}$excretion), nitric oxide (exhaled NO and blood nitrate + nitrite levels) and cytokine production (interleukin- 6 and tumor necrosis factor- $\alpha$ blood levels), and myocardial function (left ventricular $\mathrm{dp} / \mathrm{dt}_{\max }$ and $\mathrm{dp} / \mathrm{dt}_{\min }$ ) and injury (troponin I blood levels) were measured before and 12, 18, and 24 hours after peritonitis induction. Immediate post mortem liver and kidney biopsies were analysed for histomorphology (hematoxylin eosin staining) and apoptosis (TUNEL staining).

Results AVP decreased heart rate and cardiac output without otherwise affecting heart function and significantly decreased troponin I blood levels. AVP increased the rate of direct, aerobic glucose oxidation and reduced hyperlactatemia, which coincided with less severe kidney dysfunction and liver injury,

ALAT: alanine aminotransferase; ASAT: asparatate aminotransferase; AVP: arginine vasopressin; $\mathrm{CO}_{2}$ : carbon dioxide; $\mathrm{dp}_{\mathrm{dt}}$ max $:$ maximal systolic contraction; $\mathrm{dp}_{/ \mathrm{dt}_{\min }}$ : maximal diastolic relaxation; $\mathrm{FADH}_{2}$ : reduced flavine adenine dinucleotide; $\mathrm{FiO}_{2}$ : fraction of inspired oxygen; $\mathrm{H} \& \mathrm{E}$ : hematoxylin and eosin; I/E: inspiratory-to-expiratory; IL-6: interleukin-6; $\mathrm{NADH}$ : reduced nicotineamide adenine dinucleotide; $\mathrm{NO}_{2} \cdot \mathrm{NO}_{3} \cdot$ : nitrate+nitrite; $\mathrm{O}_{2}$ : oxygen; $\mathrm{PaO}_{2}$ : partial pressure of arterial oxygen; $\mathrm{PaCO}_{2}$ : partial pressure of arterial carbon dioxide; PEEP: positive end-expiratory pressure; $\tau$ : diastolic relaxation time constant; TNF $\alpha$ : tumor necrosis factor- $\alpha$; TUNEL: terminal deoxynucleotidyltransferase-mediated nick-end labeling assay; VASST: vasopressin and septic shock trial. 
attenuated systemic inflammation, and decreased kidney tubular apoptosis.

Conclusions During well-resuscitated septic shock low-dose AVP appears to be safe with respect to myocardial function and heart injury and reduces kidney and liver damage. It remains to be elucidated whether this is due to the treatment per se and/or to the decreased exogenous catecholamine requirements.

\section{Introduction}

Infusing arginine vasopressin (AVP) in vasodilatory septic shock is usually accompanied by a decrease in cardiac output and systemic oxygen $\left(\mathrm{O}_{2}\right)$ transport. It is still a matter of debate whether this vasoconstriction impedes visceral organ blood flow and thereby causes organ dysfunction [1-5]. In fact, controversial data have been reported in experimental [6-19] and clinical studies [20-22]. The vasopressin-induced vasoconstriction is also associated with reduced coronary flow, but again data are equivocal [23-27], most likely because of the variable impact of coronary flow and perfusion pressure [27]. Consequently, the use of vasopressin is still cautioned in patients with heart and/or peripheral vascular disease [2,3,5], and the multicenter Vasopressin and Septic Shock Trial (VASST) explicitly excluded patients with cardiogenic shock, ischemic heart disease, congestive heart failure, and mesenteric ischemia [27].

Given this controversy, we tested the hypothesis whether lowdose AVP infusion (supplemented with noradrenaline) is safe with respect to liver, kidney, and heart function in a clinically relevant porcine model of fecal peritonitis-induced septic shock [28]. AVP was compared with noradrenaline, and the two drugs were titrated to maintain comparable blood pressure.

\section{Materials and methods}

\section{Animal preparation, measurements, and calculations}

The study protocol was approved by the University Animal Care Committee and the Federal Authorities for Animal Research (Regierungspräsidium Tübingen, Germany, Reg.-Nr III/15). Anesthesia, surgical instrumentation, measurements have been described in detail previously [28]. Systemic, pulmonary, and hepatic (ultrasound flow probes on the portal vein and the hepatic artery) hemodynamics and gas exchange (calorimetric $\mathrm{O}_{2}$ uptake and carbon dioxide $\left(\mathrm{CO}_{2}\right)$ production, arterial, portal, hepatic, and mixed venous blood gases and oximetry), intrathoracic blood volume, extravascular lung water and indocyanine-green plasma disappearance rate (thermalgreen dye double indicator dilution), blood glucose, lactate, pyruvate, bilirubin, creatinine, troponin I, nitrate+nitrite $\left(\mathrm{NO}_{2}{ }^{-}\right.$ $+\mathrm{NO}_{3}$; chemoluminescence), TNF $\alpha$, and IL- 6 concentrations, as well as the alanine aminotransferase (ALAT) and aspartate aminotransferase (ASAT) activities were determined as described previously [28]. The bilirubin, creatinine, troponin I, IL- 6, TNF- $\alpha$ and $\mathrm{NO}_{2}{ }^{-}+\mathrm{NO}_{3}{ }^{-}$concentrations and the ALAT and ASAT activities are normalized per gram of plasma protein to correct for dilution by intravenous fluids [28]. Endogenous glu- cose production and direct, aerobic glucose oxidation were derived from the rate of appearance of stable, non-radioactively labeled $1,2,3,4,5,6-{ }^{13} \mathrm{C}_{6}$-glucose and the mixed expiratory ${ }^{13} \mathrm{CO}_{2}$, respectively, during continuous intravenous isotope infusion, after gas chromatography-mass spectrometry assessment of plasma and non-dispersive infrared spectrometry measurement of expiratory gas isotope enrichment [28]. Left ventricular function was evaluated using a pressure tip catheter (Millar Mikro-Tip ${ }^{\circledR}$, Millar Instruments, Houston, TX, USA) that allowed measuring maximal systolic contraction $\left(\mathrm{dp} / \mathrm{dt}_{\mathrm{max}}\right)$ and diastolic relaxation $\left(\mathrm{dp} / \mathrm{dt}_{\min }\right)$, as well as the frequency-independent relaxation time $(\tau)$.

Immediate postmortem liver, kidney, and heart biopsies were evaluated for histomorphologic changes (H\&E staining) and the number of apoptotic nuclei (terminal deoxynucleotidyltransferase-mediated nick-end labeling-assay (TUNEL) staining) [28]. Evidence of apoptosis was accepted only if nuclear staining was considered TUNEL positive, the scores reported representing the number of positive nuclear stainings. Slides were evaluated by a pathologist (AS) blinded for the group assignment.

\section{Experimental protocol}

Body temperature was kept between 37 and $39^{\circ} \mathrm{C}$, that is \pm $1^{\circ} \mathrm{C}$ of the pre-peritonitis value, with heating pads or cooling. Ventilator settings were [28]: tidal volume $8 \mathrm{~mL} / \mathrm{kg}$, positive end expiratory pressure (PEEP) $10 \mathrm{cmH}_{2} \mathrm{O}$, inspiratory-toexpiratory (I/E) ratio $1: 1.5$, respiratory rate adjusted to partial pressure of arterial carbon dioxide $\left(\mathrm{PaCO}_{2}\right) 35$ to $45 \mathrm{mmHg}$ (but maximum $40 \mathrm{mmHg} / \mathrm{min}$ ), peak airway pressure less than $40 \mathrm{cmH}_{2} \mathrm{O}$, fraction of inspired oxygen $\left(\mathrm{FiO}_{2}\right) 0.3$ (thereafter adjusted to maintain arterial hemoglobin $\mathrm{O}_{2}$ saturation $>$ $90 \%)$. If partial pressure of arterial oxygen $\left(\mathrm{PaO}_{2}\right) / \mathrm{FiO}_{2}$ less than $300 \mathrm{mmHg}$ or less than $200 \mathrm{mmHg}, \mathrm{I} / \mathrm{E}$ ratio was increased to $1: 1$ and PEEP to 12 or $15 \mathrm{cmH}_{2} \mathrm{O}$, respectively. Lactated Ringer's solution was infused as maintenance fluid $(7.5 \mathrm{~mL} / \mathrm{kg} / \mathrm{h}$ ), and normoglycemia (4 to $6 \mathrm{mmol} / \mathrm{L}$ ) was achieved with continuous intravenous glucose as needed. Following instrumentation, an eight-hour recovery period, and baseline data collection, peritonitis was induced by intraperitoneal instillation of $1.0 \mathrm{~g} / \mathrm{kg}$ autologous feces incubated in 100 $\mathrm{mL} 0.9 \%$ saline for 12 hours at $38^{\circ} \mathrm{C}$ [28]. Hydroxyethyl-starch $(15 \mathrm{~mL} / \mathrm{kg} / \mathrm{h}, 10 \mathrm{~mL} / \mathrm{kg} / \mathrm{h}$ if central venous or pulmonary artery occlusion pressure more than $18 \mathrm{mmHg}$ and titrated to maintain intrathoracic blood volume at 25 to $30 \mathrm{~mL} / \mathrm{kg}$ [28]) allowed the maintainence of a hyperdynamic circulation. When mean blood pressure fell by more than $10 \%$ below the pre- 
peritonitis levels over more than 15 minutes, animals randomly received either noradrenaline (controls: $n=12,4$ males, 8 females, body weight $47 \mathrm{~kg}$, range 38 to $61 \mathrm{~kg}$ ), titrated in increments of $0.05 \mu \mathrm{g} / \mathrm{kg} / \mathrm{min}$ every five minutes until the preperitonitis values was reached, or AVP $(n=12,5$ males, 7 females, body weight $46 \mathrm{~kg}$, range 36 to $54 \mathrm{~kg}$ ), titrated in increments of $1 \mathrm{ng} / \mathrm{kg} / \mathrm{min}$ every 30 minutes. According to our previous experience [28] we aimed to maintain the pre-peritonitis blood pressure, because, to the best of our knowledge, no data are available on the blood pressure necessary to maintain visceral organ perfusion in septic swine. To avoid tachycardia-induced myocardial ischemia the noradrenaline infusion rate was not further increased if heart rate was 160 beats/min or above. The AVP dose was limited to a maximum infusion rate of $5 \mathrm{ng} / \mathrm{kg} / \mathrm{min}$ and supplemented by noradrenaline if it failed to maintain blood pressure alone. After additional data collection at 12,18 , and 24 hours of peritonitis, animals were euthanized under deep anesthesia.

\section{Statistical analysis}

Data are presented as median (quartiles) unless otherwise stated. After exclusion of normal distribution using the Kolmogorov-Smirnoff-test, differences within groups were analyzed using a Friedmann analysis of variance on ranks and a subsequent Dunn's test with Bonferroni correction. As our primary hypothesis had been that AVP was safe with respect to liver and heart function in our model, intergroup differences for blood ASAT and ALAT activities as well as bilirubin and troponin I levels were tested using a Mann-Whitney rank sum test with Bonferroni adjustment for multiple comparisons. Because of the multiple statistical testing of the numerous variables measured, all other intergroup comparisons have to be interpreted in a secondary, exploratory, and hypotheses-generating, rather than confirmatory, manner.

\section{Results}

One animal in the control group died following data collection at 18 hours, and thus statistical analysis at 24 hours comprises 23 animals. Colloid resuscitation was identical in the two groups (controls: 15 (14 to 15), AVP: 14 (13 to 14) mL/ $\mathrm{kg} / \mathrm{h}$ ). AVP-treated animals did not require any additional noradrenaline during the first 12 hours of the experiment, and, consequently, the median duration and rate of the noradrenaline infusion were significantly lower (duration: 111 (0 to 282) versus 752 (531 to 935 ) minutes; infusion rate: 0.06 (0.00 to 0.10 ) versus 0.61 ( 0.33 to 0.72$) \mu \mathrm{g} / \mathrm{kg} / \mathrm{min}$ ).

Tables 1 and 2 and Figures 1 and 2 summarize the data on systemic hemodynamics and left heart function (Table 1), as well as $\mathrm{O}_{2}$ exchange, acid-base status, and metabolism (Table 2). AVP-treated animals presented with significantly lower heart rate and cardiac output. In contrast to the AVP group, maintenance of mean blood pressure was only achieved in one-third of the control animals, because the noradrenaline infusion rates were not further increased if tachycardia more than 160 beats/min occurred. Nevertheless, albeit mean blood pressure was significantly lower at 18 and 24 hours of peritonitis, one control animal only developed hypotension with a mean blood pressure less than $60 \mathrm{mmHg}$ (Figure 1). None of the other parameters of systemic and pulmonary hemodynamics showed any significant intergroup difference. Although $\mathrm{dp} / \mathrm{dt}_{\max }$ was significantly lower in the AVP-treated animals, $\mathrm{dp} / \mathrm{dt}_{\min }$ and the diastolic relaxation time $\tau$ were comparable in the two groups. Troponin I levels progressively increased in the control animals and were significantly higher than in the AVP group at the end of the experiment (Figure 2). Control animals showed a significantly higher systemic $\mathrm{O}_{2}$ transport as well as $\mathrm{O}_{2}$ uptake and $\mathrm{CO}_{2}$ production, whereas arterial blood gas tensions were nearly identical. The progressive fall of arterial $\mathrm{pH}$ and base excess was attenuated in the AVP-treated group $(P=0.069$ and $P=0.053$, respectively, at 24 hours). Although the rate of whole body glucose oxidation increased comparably, the progressive rise of endogenous glucose production rate was less pronounced in the AVP animals $(P=0.053, P=0.061$, and $P=0.053$ at 12,18 , and 24 hours of peritonitis). Consequently, the directly oxidized fraction of the glucose released was significantly higher in the AVP group, which coincided with significantly lower arterial lactate levels at 18 and 24 hours.

Table 3 and Figures 3, 4, 5 and 6 summarize the parameters of visceral organ blood flow, $\mathrm{O}_{2}$ kinetics, acid-base status, and function. Except for a lower portal venous flow $(P=0.053$ at 24 hours), liver hemodynamics and $\mathrm{O}_{2}$ exchange did not significantly differ between the two groups. Nevertheless, AVP attenuated the portal and hepatic venous acidosis (Table 3 ) and blunted the otherwise significant rise in serum transaminase activities and bilirubin levels (Figures 3, 4 and 5). AVP prevented the time-dependent fall in urine output so that diuresis was significantly higher between 12 and 24 hours (Table 3). Renal dysfunction with reduced creatinine clearance (Table 3) and increased blood creatinine levels (Figure 6) was less severe, while fractional $\mathrm{Na}^{+}$excretion was significantly higher in the AVP-treated animals (Table 3).

Table 4 shows the parameters of the inflammatory response. Although the increase in blood $\mathrm{NO}_{2}{ }^{-}+\mathrm{NO}_{3}{ }^{-}$and $\mathrm{TNF} \alpha$ levels was comparable, AVP was associated with significantly lower IL-6 concentrations and expired nitric oxide (NO).

Histomorphologic evaluation showed some non-specific subcapsular inflammatory cell infiltration and a few biliary tract concrements in the liver, and tubular swelling in the kidney; however, this was without any intergroup difference, and no pathologic findings at all in the myocardium. Although TUNELpositive nuclei were absent or rare (without intergroup difference) in the heart and the liver, respectively, AVP-treated animals showed less TUNEL-positive renal tubular nuclei (3 (3 to 9) versus 11 (5 to 15$)$, respectively, $P=0.061$ ). 
Parameters of systemic hemodynamics and cardiac function in the control $(n=12, n=11$ at 24 hours of peritonitis) and AVP ( $n=12)$ groups

\begin{tabular}{|c|c|c|c|c|c|}
\hline & & Before peritonitis & 12 hours peritonitis & 18 hours peritonitis & 24 hours peritonitis \\
\hline Heart rate & Control & 92 (87 to 104$)$ & $128(105 \text { to } 153)^{b}$ & $155(129 \text { to } 160)^{b}$ & $158(154 \text { to } 160)^{b}$ \\
\hline (beats/min) & AVP & 85 (75 to 95$)$ & $96(76 \text { to } 102)^{a}$ & $87(74 \text { to } 105)^{a}$ & $103(84 \text { to } 112)^{a, b}$ \\
\hline Cardiac output & Control & 105 (95 to 119$)$ & 122 (101 to 129$)$ & $155(125 \text { to } 167)^{b}$ & $131(117 \text { to } 183)^{b}$ \\
\hline$(\mathrm{mL} / \mathrm{kg} / \mathrm{min})$ & AVP & 105 (95 to 107$)$ & 95 (84 to 105$)$ & $97(71 \text { to } 122)^{a}$ & $104(82$ to 136$)$ \\
\hline Mean arterial & Control & 98 (93 to 105$)$ & 95 (82 to 108$)$ & $89(72 \text { to } 91)^{b}$ & $78(63 \text { to } 89)^{b}$ \\
\hline pressure $(\mathrm{mmHg})$ & AVP & 95 (90 to 104$)$ & 96 (90 to 111$)$ & $99(91 \text { to } 104)^{a}$ & $98(90 \text { to } 102)^{\mathrm{a}}$ \\
\hline Mean pulmonary artery & Control & 27 (26 to 30$)$ & $37(34 \text { to } 42)^{b}$ & $36(32 \text { to } 41)^{b}$ & $39(34 \text { to } 44)^{b}$ \\
\hline pressure $(\mathrm{mmHg})$ & AVP & 28 (26 to 30$)$ & $37(31 \text { to } 43)^{b}$ & $37(36 \text { to } 40)^{b}$ & $40(37 \text { to } 44)^{b}$ \\
\hline Central venous & Control & 12 (12 to 14$)$ & $14(12$ to 16$)$ & $15(13 \text { to } 18)^{b}$ & $19(14 \text { to } 21)^{b}$ \\
\hline pressure $(\mathrm{mmHg})$ & AVP & 12 (12 to 13$)$ & $16(14 \text { to } 17)^{\mathrm{b}}$ & $16(14 \text { to } 17)^{\mathrm{b}}$ & $17(16 \text { to } 19)^{b}$ \\
\hline Pulmonary artery occlusion & Control & 14 (13 to 16$)$ & 16 (14 to 17$)$ & 16 (13 to 18$)$ & $17(14 \text { to } 19)^{b}$ \\
\hline pressure $(\mathrm{mmHg})$ & AVP & 13 (12 to 15$)$ & 16 (13 to 16$)$ & $17(15 \text { to } 18)^{b}$ & $18(18 \text { to } 19)^{b}$ \\
\hline Stroke volume & Control & $1.2(11$ to 1.4$)$ & $0.9(0.9 \text { to } 1.0)^{b}$ & $1.0(0.9$ to 1.1$)$ & $0.9(0.8$ to 1.2$)$ \\
\hline$(\mathrm{mL} / \mathrm{kg})$ & AVP & $1.2(1.0$ to 1.3$)$ & $1.0(0.9 \text { to } 1.3)^{\mathrm{b}}$ & 1.0 (0.9 to 1.2$)$ & $1.0(0.9$ to 1.1$)$ \\
\hline Intrathoracic blood volume & Control & 27 (22 to 35 ) & 25 (23 to 26 ) & 28 (26 to 31$)$ & 27 (26 to 32 ) \\
\hline$(\mathrm{mL} / \mathrm{kg})$ & AVP & 26 (21 to 29 ) & 24 (21 to 28 ) & 29 (24 to 31$)$ & 21 (20 to 28 ) \\
\hline $\mathrm{DP} / \mathrm{dt}_{\max }$ & Control & 1355 (1246 to 1415$)$ & 1774 (1663 to 1980$)$ & 2011 (1291 to 2215$)$ & 1532 (1119 to 1979$)$ \\
\hline$(\mathrm{mmHg} / \mathrm{sec})$ & AVP & 1137 (957 to 1410$)$ & $793(758 \text { to } 844)^{a}$ & $893(739$ to 1310$)$ & $915(730 \text { to } 1404)^{a}$ \\
\hline $\mathrm{DP} / \mathrm{dt}_{\min }$ & Control & $-1296(-1329$ to -1134$)$ & $-1444(-1556$ to -1093$)$ & $-1421(-1709$ to -948$)$ & $-1243(-1493$ to -1038$)$ \\
\hline$(\mathrm{mmHg} / \mathrm{sec})$ & AVP & $-1321(-1476$ to -1128$)$ & $-1065(-1114$ to -890$)$ & $-1202(-1311$ to -930$)$ & $-1109(-1473 \text { to }-887)^{b}$ \\
\hline$\tau$ & Control & 22 (20 to 22 ) & 25 (17 to 26$)$ & 23 (18 to 26$)$ & 20 (18 to 25$)$ \\
\hline (ms) & AVP & 22 (20 to 25$)$ & 19 (15 to 20$)$ & 21 (16 to 23 ) & $19(15 \text { to } 25)^{b}$ \\
\hline
\end{tabular}

All data are median (quartiles). a $P<0.05$ between norepinephrine- and AVP-treated animals; ${ }^{b} P<0.05$ within groups versus before peritonitis. $\mathrm{AVP}=$ arginine vasopressin; $\mathrm{dp} / \mathrm{dt}_{\max }=$ maximal systolic contraction; $\mathrm{dp} / \mathrm{dt}_{\min }=$ maximal diastolic relaxation.

\section{Discussion}

The aim of the present study was to test the hypothesis whether low-dose AVP infusion is safe for heart and visceral organ function in a clinically relevant, resuscitated, and hyperdynamic porcine model of fecal peritonitis-induced septic shock. AVP supplemented with noradrenaline was compared with noradrenaline alone, which were titrated to maintain comparable blood pressure. The key findings were that: AVP decreased heart rate and cardiac output without affecting myocardial relaxation, and significantly decreased troponin I blood levels; increased the rate of direct, aerobic glucose oxidation, and reduced hyperlactatemia; attenuated kidney dysfunction as well as liver injury, which coincided with less severe systemic inflammatory response.

In our experiment, left ventricular $\mathrm{dp} / \mathrm{dt}_{\max }$ was significantly lower in the AVP group, whereas $\mathrm{dp} / \mathrm{dt}_{\min }$ remained unchanged. Thus our experiment seems to confirm negative inotrope properties of AVP in isolated hearts [23,24] and endotoxin-challenged rabbits [25]. As first derivatives of pressure, $\mathrm{dp} / \mathrm{dt}_{\max }$ and $\mathrm{dp} / \mathrm{dt}_{\min }$ crucially depend on heart rate. In the mentioned studies, however, heart rate was not affected at all $[23,24]$ or decreased by less than $10 \%$ only [25]. Furthermore, an unresuscitated model with endotoxin-induced cardiac dysfunction [25] or AVP decreased coronary blood flow below baseline levels [23,24]. Clearly, as we did not measure coronary blood flow, we cannot exclude a vasoconstrictionrelated reduction in coronary perfusion. Nevertheless, it is unlikely that AVP caused myocardial ischemia: troponin I levels progressively increased in the control animals only and were significantly higher than in the AVP group at the end of the experiment. Our findings are in sharp contrast to data by Müller and colleagues, who recently reported unchanged systolic and compromised diastolic heart function during incremental AVP infusion in swine with transient myocardial ischemia [18]. These authors also studied a hypodynamic 
Parameters of systemic gas exchange, metabolism and acid-base status in the control $(n=12, n=11$ at 24 hours of peritonitis) and $\operatorname{AVP}(\mathbf{n}=12)$ groups

\begin{tabular}{|c|c|c|c|c|c|}
\hline & & Before peritonitis & 12 hours peritonitis & 18 hours peritonitis & 24 hours peritonitis \\
\hline Arterial $\mathrm{PO}_{2}$ & Control & 166 (160 to 179$)$ & $144(124 \text { to } 153)^{b}$ & $106(93 \text { to } 121)^{b}$ & $87(80 \text { to } 114)^{b}$ \\
\hline$(\mathrm{mmHg})$ & AVP & 163 (154 to 179$)$ & $144(128 \text { to } 170)^{b}$ & $124(96 \text { to } 150)^{b}$ & $96(84 \text { to } 138)^{b}$ \\
\hline Arterial $\mathrm{PCO}_{2}$ & Control & 37 (35 to 39) & $41(40 \text { to } 44)^{b}$ & $41(39 \text { to } 45)^{b}$ & $44(39 \text { to } 46)^{b}$ \\
\hline$(\mathrm{mmHg})$ & AVP & 36 (34 to 40$)$ & $40(39 \text { to } 43)^{b}$ & $41(38 \text { to } 44)^{b}$ & $42(39 \text { to } 45)^{b}$ \\
\hline Extravascular lung water & Control & 4.4 (3.0 to 6.0 ) & 4.8 (1.5 to 7.0$)$ & 5.8 (1.4 to 8.6$)$ & $7.4(5.5 \text { to } 8.6)^{b}$ \\
\hline$(\mathrm{mL} / \mathrm{kg})$ & AVP & 3.3 (2.7 to 5.0$)$ & $7.4(1.8 \text { to } 9.6)^{b}$ & $9.0(1.1 \text { to } 11.0)^{b}$ & $5.9(3.4 \text { to } 8.4)^{b}$ \\
\hline Systemic $\mathrm{O}_{2}$ delivery & Control & 10 (9 to 11$)$ & $14(11 \text { to } 18)^{b}$ & $19(16 \text { to } 23)^{b}$ & $17(12 \text { to } 21)^{b}$ \\
\hline$(\mathrm{mL} / \mathrm{kg} / \mathrm{min})$ & AVP & 11 (10 to 12$)$ & 11 (11 to 13$)$ & $12(8 \text { to } 15)^{a}$ & 13 (10 to 16$)$ \\
\hline Systemic $\mathrm{O}_{2}$ uptake & Control & $4.9(4.0$ to 5.3$)$ & 4.4 (3.7 to 5.7$)$ & $6.0(4.5 \text { to } 7.2)^{b}$ & $6.0(5.3 \text { to } 6.8)^{b}$ \\
\hline$(\mathrm{mL} / \mathrm{kg} / \mathrm{min})$ & AVP & 4.7 (4.2 to 4.8$)$ & $4.6(3.9 \text { to } 4.7)^{\mathrm{b}}$ & $4.7(4.2 \text { to } 4.9)^{a}$ & $4.7(4.2 \text { to } 5.6)^{\mathrm{a}}$ \\
\hline Systemic $\mathrm{CO}_{2}$ production & Control & 3.1 (2.7 to 3.5$)$ & $3.5(3.0 \text { to } 4.1)^{b}$ & $4.1(3.7 \text { to } 4.5)^{b}$ & $4.4(4.0 \text { to } 4.8)^{b}$ \\
\hline$(\mathrm{mL} / \mathrm{kg} / \mathrm{min})$ & AVP & $3.0(2.7$ to 3.4$)$ & 3.2 (2.9 to 3.6$)$ & $3.4(3.1 \text { to } 3.6)^{a, b}$ & 3.5 (3.2 to 3.8$)^{a, b}$ \\
\hline Endogenous glucose & Control & 2.7 (2.4 to 3.4$)$ & $5.6(4.5 \text { to } 6.3)^{\mathrm{b}}$ & $7.2(5.6 \text { to } 8.4)^{\mathrm{b}}$ & $7.7(7.1 \text { to } 10.2)^{b}$ \\
\hline production (mg/kg/min) & AVP & 2.5 (2.2 to 2.9$)$ & $4.5(4.0 \text { to } 4.8)^{b}$ & $4.9(4.7 \text { to } 6.8)^{b}$ & $6.6(5.0 \text { to } 7.5)^{\mathrm{b}}$ \\
\hline Systemic glucose & Control & $1.9(1.4$ to 2.9$)$ & $3.2(2.1 \text { to } 3.4)^{b}$ & $3.8(3.1 \text { to } 4.3)^{b}$ & $3.8(3.4 \text { to } 4.5)^{b}$ \\
\hline oxidation (mg/kg/min) & AVP & $1.9(1.6$ to 2.4$)$ & $2.9(2.5 \text { to } 3.8)^{b}$ & $3.7(2.9 \text { to } 3.9)^{b}$ & $3.8(3.2 \text { to } 4.2)^{b}$ \\
\hline Glucose oxidation/production ratio (\%) & Control & $74(50$ to 104$)$ & $54(51 \text { to } 62)^{b}$ & 52 (50 to 56$)$ & $49(44 \text { to } 55)^{b}$ \\
\hline & AVP & 79 (60 to 93$)$ & $64(57 \text { to } 72)^{a}$ & $62(57 \text { to } 64)^{a, b}$ & $57(53 \text { to } 65)^{a, b}$ \\
\hline Arterial lactate & Control & 0.9 (0.8 to 1.0$)$ & $1.1(1.0 \text { to } 1.3)^{\mathrm{b}}$ & $2.0(1.3 \text { to } 3.6)^{b}$ & $2.3(1.8 \text { to } 4.1)^{\mathrm{b}}$ \\
\hline$(\mathrm{mmol} / \mathrm{L})$ & AVP & $0.9(0.8$ to 1.0$)$ & $0.9(0.8$ to 1.1$)$ & $1.2(1.0 \text { to } 1.5)^{a, b}$ & $1.5(1.3 \text { to } 1.9)^{a, b}$ \\
\hline Arterial & Control & 8 (7 to 9$)$ & 12 (11 to 13$)$ & $13(12 \text { to } 16)^{a}$ & $15(13 \text { to } 17)^{a}$ \\
\hline lactate/pyruvate ratio & AVP & $9(8$ to 10$)$ & 12 (11 to 13$)$ & $12(11 \text { to } 13)^{a}$ & $14(13 \text { to } 15)^{a}$ \\
\hline \multirow[t]{2}{*}{ Arterial $\mathrm{pH}$} & Control & 7.56 (7.55 to 7.59$)$ & $7.50(7.45 \text { to } 7.53)^{b}$ & $7.47(7.44 \text { to } 7.49)^{b}$ & $7.44(7.38 \text { to } 7.45)^{b}$ \\
\hline & AVP & 7.54 (7.49 to 7.57$)$ & $7.51(7.49 \text { to } 7.52)^{b}$ & $7.49(7.45 \text { to } 7.53)^{b}$ & $7.49(7.44 \text { to } 7.51)^{b}$ \\
\hline Arterial base excess & Control & 10.3 (8.8 to 12.3$)$ & 9.9 (7.0 to 11.3$)$ & $6.0(3.4 \text { to } 8.0)^{b}$ & $4.1(-0.2 \text { to } 6.2)^{b}$ \\
\hline$(\mathrm{mmol} / \mathrm{L})$ & AVP & $9.3(7.9$ to 11.0$)$ & 9.6 (8.3 to 11.1$)$ & 8.9 (6.1 to 9.4$)$ & 7.1 (3.9 to 10.7 ) \\
\hline
\end{tabular}

All data are median (quartiles). a $P<0.05$ between norepinephrine- and AVP-treated animals; ${ }^{b} P<0.05$ within groups versus before peritonitis. $\mathrm{AVP}=$ arginine vasopressin; $\mathrm{PCO}_{2}=$ partial pressure of carbon dioxide; $\mathrm{PO}_{2}=$ partial pressure of oxygen.

model characterized by a reduced cardiac output resulting from myocardial dysfunction, while we investigated fluid-resuscitated animals with a sustained increase in cardiac output. In addition, Müller and colleagues infused AVP alone, while we combined AVP with noradrenaline. In fact, the current rationale of AVP use comprises a supplemental infusion, targeted to restore vasopressin levels, simultaneously with catecholamines rather than AVP alone [29]. It remains open whether the results reported by Müller and colleagues were due to the AVP-related vasoconstriction, that is, afterload-dependent and/or related to coronary hypoperfusion, or to a genuine myocardial effect. This issue, however, is critical in the discussion on cardiac effects of AVP: 'cardiac efficiency', that is, the prod- uct of left ventricular pressure times heart rate normalized for myocardial $\mathrm{O}_{2}$ consumption, was well maintained under constant flow conditions [26]. Finally, the significantly reduced noradrenaline requirements may have contributed to the less severe myocardial injury [30]. In the control group, maintaining blood pressure at pre-peritonitis levels necessitated high noradrenaline infusion rates, which were reported to cause myocardial injury due to increased workload [31] and reduced metabolic efficiency resulting from enhanced fatty acid oxidation [32].

Despite the lower portal venous flow infusing AVP did not have any detrimental effect on liver $\mathrm{O}_{2}$ exchange and, moreover, 
Figure 1

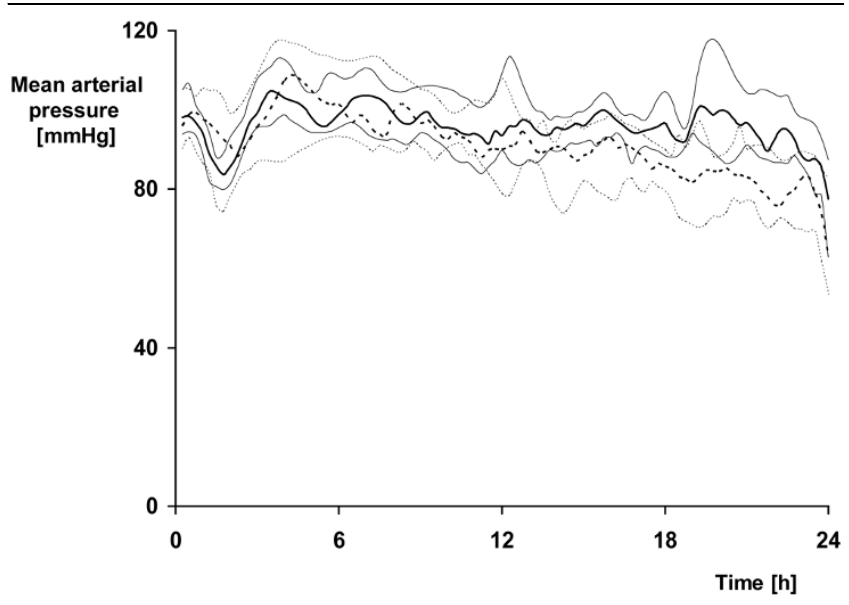

Mean blood pressure in the control and AVP animals. Control $=$ dotted line; $n=12, n=11$ from 20 to 24 hours. Arginine vasopressin (AVP) animals $=$ straight line; $n=12$. Data are median (quartiles) and represent a minute-to-minute average based on continuous recording.

was associated with less severe hepatic venous metabolic acidosis and attenuated liver injury. Furthermore, AVP infusion resulted in significantly less severe kidney dysfunction. Controversial effects were reported on the effects of AVP infusion on visceral organ blood flow and function during large animal sepsis and septic shock: although AVP decreased mesenteric arterial and portal venous flow during porcine and ovine bacterial sepsis $[13,15,16]$ or endotoxemia $[6,7,10]$, other studies found unchanged hepato-splanchnic perfusion when vasopressin or terlipressin were infused during hyperdynamic porcine endotoxemia and ovine fecal peritonitis $[8,10,19]$. The effect of AVP on the kidney macrocirculation was even more

\section{Figure 2}

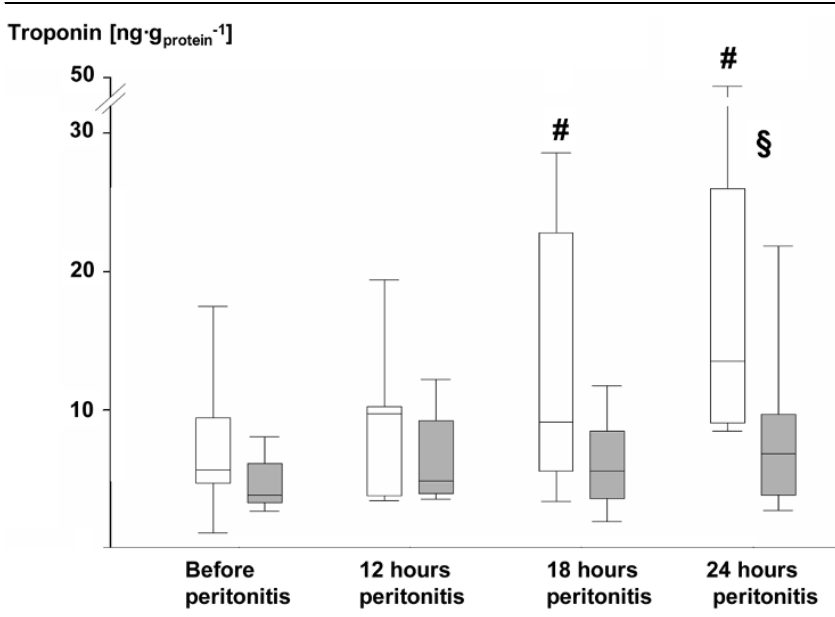

Blood troponin I levels in the control and AVP animals. control = open whiskers; $n=12, n=11$ at 24 hours. Arginine vasopressin (AVP) animals $=$ grey whiskers; $\mathrm{n}=12$. Data are median (quartiles, range). \# $P<$ 0.05 within groups versus before peritonitis; $\S P<0.05$ between norepinephrine- and AVP-treated animals. heterogenous, in as much decreased [10], unchanged [13,16], and even increased [7] renal blood flow were reported. It should be emphasized that a fall in regional blood flow below baseline levels associated with signs of organ ischemia, for example, regional venous acidosis and/or increased lactate concentrations, only occurred in hypodynamic models with a sustained decrease in cardiac output $[7,10]$ and/or with AVP doses higher than currently recommended $[15,16]$. In fact, Sun and colleagues demonstrated during ovine fecal peritonitis that both low-dose vasopressin alone and in combination with noradrenaline were associated with less severe hyperlactatemia and tissue acidosis than with noradrenaline alone, which ultimately resulted in improved survival [8]. In endotoxic swine infusing low doses of the AVP analogue terlipressin also caused hyperlactatemia, which, however, did not originate from the hepato-splanchnic system and was even associated with attenuated portal and hepatic venous metabolic acidosis [33].

AVP did not affect creatinine clearance, and fractional $\mathrm{Na}^{+}$ excretion was significantly increased. Therefore, it could be argued that AVP deteriorated or, at best, did not influence kidney function [34], which would be in contrast with previous reports of improved renal function in experimental models $[9,13,35]$ and clinical investigations $[22,36]$. It should be noted, however, that AVP significantly attenuated the otherwise progressive increase in creatinine blood levels. Despite its value as a marker of kidney injury, blood creatinine concentrations may not be closely correlated with creatinine clearance in the pig, because in this species some basal tubular creatinine secretion may be present [37]. Moreover, in the context of the significantly higher urine output, the lower blood creatinine levels, and the attenuated tubular TUNEL staining, the significantly higher fractional $\mathrm{Na}^{+}$excretion probably mirrors the physiologic response to AVP [38] rather than deteriorated tubular function: intravenous AVP increased fractional $\mathrm{Na}^{+}$elimination both under healthy $[39,40]$ and pathologic conditions $[35,41]$. Finally, the reduced noradrenaline requirements may have also contributed to the higher fractional $\mathrm{Na}^{+}$ excretion: noradrenaline per se was demonstrated to reduce $\mathrm{Na}^{+}$elimination $[42,43]$.

Several mechanisms may explain the AVP-related less severe organ dysfunction and tissue injury. First, AVP was associated with significantly lower IL-6 levels, that is, an attenuated systemic inflammatory response, which is in good agreement with the anti-inflammatory properties of AVP reported in endotoxic mice [44]. In addition, infusing AVP reduced the amount of exhaled NO, which confirms our own data during terlipressin infusion in endotoxic swine [33], as well as the inhibition of the inducible isoform of the NO synthase in endotoxic rats with biliary cirrhosis [45]. In addition to anti-inflammatory properties of vasopressin per se, the lower noradrenaline doses may have attenuated the inflammatory response: catecholamines may mimick $[46]$ and/or enhance $[47,48]$ the inflammatory effects 
Parameters of visceral organ (liver, kidney) hemodynamics, acid-base status and organ function in the control ( $n=12, n=11$ at 24 hours of peritonitis) and AVP $(n=12)$ groups

\begin{tabular}{|c|c|c|c|c|c|}
\hline & & Before peritonitis & 12 hours peritonitis & 18 hours peritonitis & 24 hours peritonitis \\
\hline \multirow[t]{2}{*}{ Portal vein flow (mL/kg/min) } & Control & 18 (15 to 22$)$ & $29(21 \text { to } 31)^{b}$ & $29(24 \text { to } 34)^{b}$ & $26(24 \text { to } 30)^{b}$ \\
\hline & AVP & $18(16$ to 20$)$ & $24(20 \text { to } 31)^{b}$ & 22 (16 to 27$)$ & 20 (16 to 24$)$ \\
\hline \multirow[t]{2}{*}{ Hepatic artery flow $(\mathrm{mL} / \mathrm{kg} / \mathrm{min})$} & Control & $1.7(0.4$ to 2.1$)$ & $1.4(0.9$ to 2.9$)$ & $1.6(1.3$ to 3.5$)$ & $2.1(1.1 \text { to } 3.6)^{b}$ \\
\hline & AVP & $0.6(0.2$ to 1.6$)$ & $1.6(0.2 \text { to } 3.2)^{b}$ & $1.9(0.3 \text { to } 3.3)^{b}$ & $3.0(0.3 \text { to } 5.5)^{b}$ \\
\hline \multirow{2}{*}{$\begin{array}{l}\text { Hepatic } \mathrm{O}_{2} \text { delivery } \\
(\mathrm{mL} / \mathrm{kg} / \mathrm{min})\end{array}$} & Control & $1.0(0.9$ to 1.5$)$ & $2.9(2.5 \text { to } 3.7)^{b}$ & $3.0(2.0 \text { to } 3.5)^{b}$ & $2.6(1.8 \text { to } 3.1)^{b}$ \\
\hline & AVP & $1.2(1.0$ to 1.5$)$ & $2.5(1.9 \text { to } 3.0)^{b}$ & $2.2(1.7 \text { to } 3.0)^{b}$ & $2.3(1.4 \text { to } 2.7)^{b}$ \\
\hline \multirow[t]{2}{*}{ Portal vein $\mathrm{O}_{2}$ saturation (\%) } & Control & 58 (55 to 64$)$ & $78(76 \text { to } 81)^{b}$ & $77(71 \text { to } 79)^{b}$ & $72(67 \text { to } 74)^{b}$ \\
\hline & AVP & 60 (55 to 63 ) & $78(68 \text { to } 83)^{b}$ & $72(65 \text { to } 75)^{b}$ & $69(63 \text { to } 71)^{b}$ \\
\hline \multirow[t]{2}{*}{ Hepatic vein $\mathrm{O}_{2}$ saturation (\%) } & $\begin{array}{l}\text { Control } \\
\text { AVP }\end{array}$ & 25 (24 to 72 ) & $63(54 \text { to } 65)^{b}$ & $58(52 \text { to } 65)^{b}$ & $53(44 \text { to } 56)^{b}$ \\
\hline & & 30 (20 to 55$)$ & $66(50 \text { to } 70)^{b}$ & $54(42 \text { to } 61)^{b}$ & $55(50 \text { to } 58)^{b}$ \\
\hline \multirow[t]{2}{*}{ Portal drained viscera $\mathrm{O}_{2}$ extraction (\%) } & $\begin{array}{l}\text { Control } \\
\text { AVP }\end{array}$ & 40 (37 to 46$)$ & $21(18 \text { to } 24)^{b}$ & $21(18 \text { to } 25)^{b}$ & $27(24 \text { to } 34)^{b}$ \\
\hline & & 43 (37 to 44$)$ & $22(17 \text { to } 35)^{b}$ & $22(19 \text { to } 31)^{b}$ & $30(25 \text { to } 34)^{b}$ \\
\hline Hepatic $\mathrm{O}_{2}$ uptake & Control & $0.6(0.4$ to 0.8$)$ & $0.6(0.4$ to 0.9$)$ & $0.7(0.5$ to 1.1$)$ & $0.6(0.4$ to 0.8$)$ \\
\hline$(\mathrm{mL} / \mathrm{kg} / \mathrm{min})$ & AVP & 0.6 (0.5 to 0.9$)$ & 0.8 (0.5 to 0.9$)$ & 0.7 (0.4 to 1.0$)$ & 0.5 (0.3 to 0.7$)$ \\
\hline Portal vein & Control & 10 (9 to 12$)$ & $14(12$ to 15$)$ & 15 (13 to 17$)$ & $16(13 \text { to } 18)^{a}$ \\
\hline lactate/pruvate ratio & AVP & 11 (10 to 12$)$ & $13(11$ to 15$)$ & $14(13$ to 15$)$ & $15(13 \text { to } 17)^{a}$ \\
\hline Hepatic vein & Control & $9(8$ to 10$)$ & 12 (10 to 15$)$ & 13 (12 to 15$)$ & $14(12 \text { to } 18)^{a}$ \\
\hline lactate/pruvate ratio & AVP & $8(7$ to 12$)$ & $12(10$ to 15$)$ & $11(10$ to 16$)$ & $13(11 \text { to } 16)^{a}$ \\
\hline \multirow[t]{2}{*}{ Portal vein $\mathrm{pH}$} & Control & 7.49 (7.46 to 7.52$)$ & 7.46 (7.42 to 7.48$)$ & $7.41(7.38 \text { to } 7.45)^{b}$ & $7.37(7.33 \text { to } 7.42)^{b}$ \\
\hline & AVP & 7.48 (7.43 to 7.51$)$ & $7.47(7.44 \text { to } 7.49)^{b}$ & $7.44(7.39 \text { to } 7.47)^{b}$ & $7.42(7.37 \text { to } 7.43)^{b}$ \\
\hline \multirow[t]{2}{*}{ Hepatic vein $\mathrm{pH}$} & Control & 7.49 (7.47 to 7.53$)$ & 7.48 (7.43 to 7.49$)$ & $7.43(7.40 \text { to } 7.46)^{b}$ & $7.39(7.33 \text { to } 7.44)^{b}$ \\
\hline & AVP & 7.49 (7.44 to 7.54$)$ & 7.47 (7.44 to 7.50$)$ & $7.43(7.39 \text { to } 7.48)^{b}$ & $7.44(7.40$ to 7.46$)$ \\
\hline \multirow[t]{2}{*}{$\begin{array}{l}\text { Portal vein base excess } \\
\qquad(\mathrm{mmol} / \mathrm{L})\end{array}$} & Control & 10.8 (9.5 to 12.5$)$ & $10.2(8.1 \text { to } 11.2)^{b}$ & $6.5(3.0 \text { to } 8.2)^{b}$ & $4.8(0.1 \text { to } 6.2)^{b}$ \\
\hline & AVP & $9.8(7.8$ to 12.4$)$ & $9.2(7.3$ to 10.4$)$ & 9.5 (6.0 to 10.6$)$ & $8.9(3.0 \text { to } 11.0)^{a}$ \\
\hline \multirow[t]{2}{*}{ Hepatic vein base excess (mmol/L) } & Control & $12.6(10.5$ to 14.2$)$ & $11.1(7.9 \text { to } 12.2)^{\mathrm{b}}$ & $7.6(5.1 \text { to } 8.9)^{b}$ & $5.8(0.5 \text { to } 7.4)^{b}$ \\
\hline & AVP & $11.6(10.1$ to 14.8$)$ & $10.5(8.5 \text { to } 12.2)^{b}$ & $9.8(4.5 \text { to } 11.1)^{b}$ & $9.0(3.8 \text { to } 11.8)^{b}$ \\
\hline ICG plasma & Control & 20 (19 to 23$)$ & 17 (13 to 31$)$ & 14 (10 to 34$)$ & $13(8 \text { to } 22)^{b}$ \\
\hline disappearance rate $(\% / \mathrm{min})$ & AVP & 15 (11 to 19$)$ & $14(10$ to 18$)$ & 13 (8 to 15$)$ & 12 (12 to 15$)$ \\
\hline \multirow[t]{2}{*}{$\begin{array}{l}\text { Urine output } \\
(\mathrm{mL} / \mathrm{kg} / \mathrm{h})\end{array}$} & Control & \multicolumn{2}{|c|}{$5.4(4.1$ to 7.2$)$} & \multicolumn{2}{|c|}{$3.2(2.3 \text { to } 4.8)^{b}$} \\
\hline & AVP & \multicolumn{2}{|c|}{6.7 (5.9 to 8.0$)$} & \multicolumn{2}{|c|}{$5.6(4.6 \text { to } 8.6)^{a}$} \\
\hline \multirow[t]{2}{*}{$\begin{array}{l}\text { Creatinine clearance } \\
(\mathrm{mL} / \mathrm{min})\end{array}$} & Control & \multicolumn{2}{|c|}{$80(67$ to 88$)$} & \multicolumn{2}{|c|}{$64(35 \text { to } 85)^{c}$} \\
\hline & AVP & \multicolumn{2}{|c|}{79 (60 to 98$)$} & \multicolumn{2}{|c|}{$61(44 \text { to } 73)^{c}$} \\
\hline \multirow[t]{2}{*}{ Fractional $\mathrm{Na}^{+}$excretion (\%) } & $\begin{array}{l}\text { Control } \\
\text { AVP }\end{array}$ & \multicolumn{2}{|c|}{$5.6(4.8$ to 7.7$)$} & \multicolumn{2}{|c|}{$3.0(2.5$ to 5.1$)$} \\
\hline & & \multicolumn{2}{|c|}{$8.3(6.4 \text { to } 10.0)^{\mathrm{a}}$} & \multicolumn{2}{|c|}{$9.5(7.2 \text { to } 10.7)^{\mathrm{a}}$} \\
\hline
\end{tabular}

Data on urine flow, creatinine clearance, and fractional $\mathrm{Na}^{+}$excretion refer to the first and second half of the experiment, respectively. All data are median (quartiles). a $P<0.05$ between norepinephrine- and AVP-treated animals; ${ }^{b} P<0.05$ within groups versus before peritonitis. $A V P=$ arginine vasopressin; ICG $=$ indocyanine-green dye. 
Figure 3

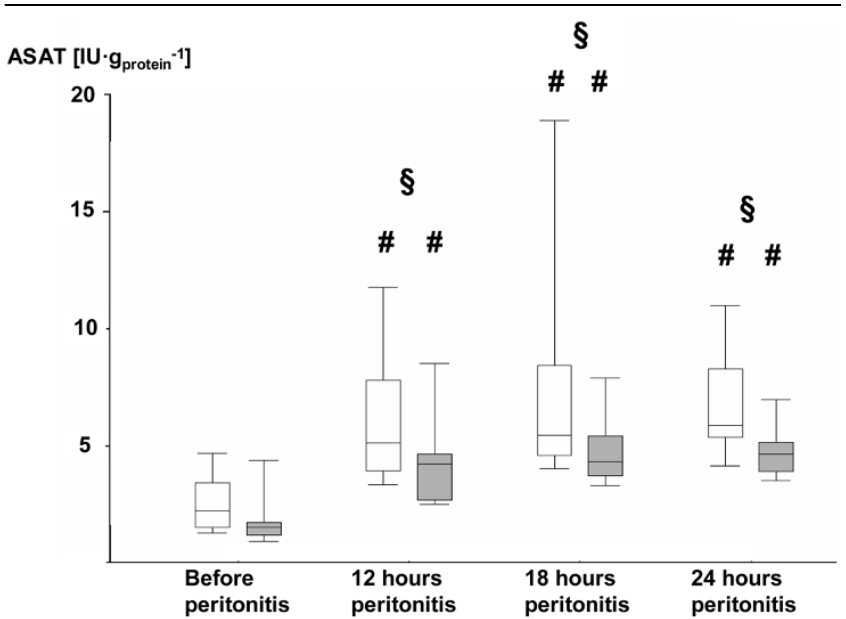

Blood ASAT activities as levels in the control and AVP animals. Control $=$ open whiskers; $n=12, n=11$ at 24 hours. Arginine vasopressin (AVP) animals $=$ grey whiskers, $\mathrm{n}=12$. Data are median (quartiles, range). \# $P<0.05$ within groups versus before peritonitis; $\S P<0.05$ between norepinephrine- and AVP-treated animals. ASAT = asparatate aminotransferase.

of endotoxin. Second, AVP was affiliated with a smaller rise in the endogenous glucose production rate, while glucose oxidation was identical. Consequently, the percentage of direct, aerobic glucose oxidation as a fraction of endogenous glucose release was significantly increased. Such a switch in fuel utilization to the preferential use of glucose improves the yield of oxidative phosphorylation: the ratio of ATP synthesis to $\mathrm{O}_{2}$ consumption is higher for glycolysis than for $\beta$-oxidation, because reduced nicotineamide adenine dinucleotide

Figure 4

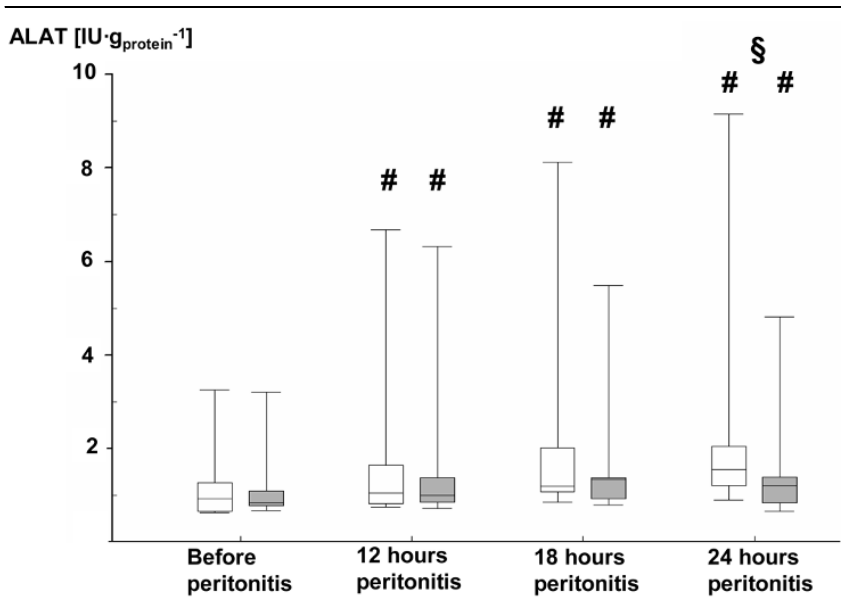

Blood ALAT levels in the control and AVP animals. Control = open whiskers; $n=12, n=11$ at 24 hours. Arginine vasopressin (AVP) animals $=$ grey whiskers; $\mathrm{n}=12$. Data are median (quartiles, range). \# $P<$ 0.05 within groups versus before peritonitis; $\S P<0.05$ between norepinephrine- and AVP-treated animals. ALAT $=$ alanine aminotransferase.

\section{Figure 5}

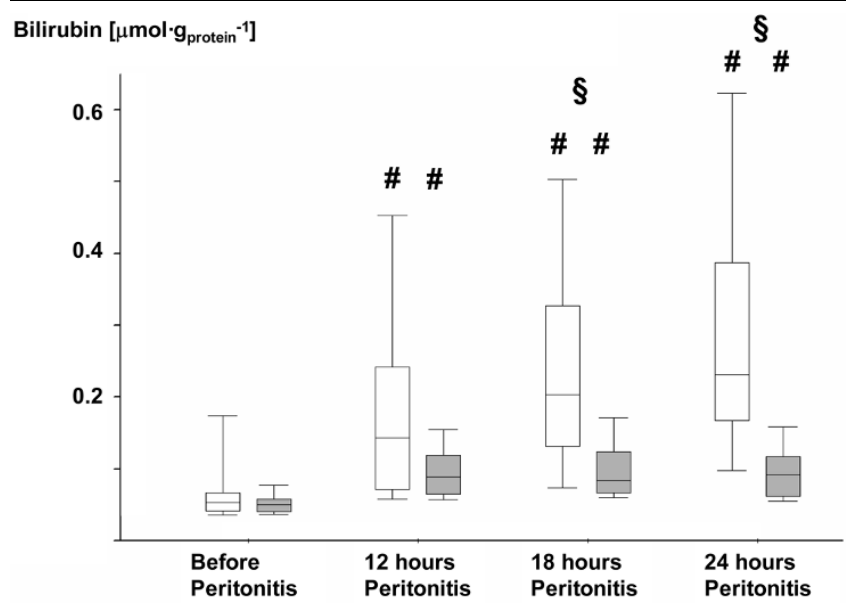

Blood bilirubin levels in the control and AVP animals. Control = open whiskers; $n=12, n=11$ at 24 hours. Arginine vasopressin (AVP) animals $=$ grey whiskers; $\mathrm{n}=12$. Data are median (quartiles, range). \# $P<$ 0.05 within groups versus before peritonitis; $\S P<0.05$ between norepinephrine- and AVP-treated animals.

(NADH) as an electron donor provides three coupling sites rather than two only provided by reduced flavine adenine dinucleotide $\left(\mathrm{FADH}_{2}\right)$ [49]. Again, it remains open whether this effect is due to AVP per se and/or the reduced catecholamine requirements: Noradrenaline increases endogenous glucose release [50], and Regueria and colleagues showed improved liver mitochondrial function during noradrenaline administration in endotoxic swine [51], whereas other authors emphasized the catecholamine-induced derangement of metabolic efficiency [52].

\section{Figure 6}

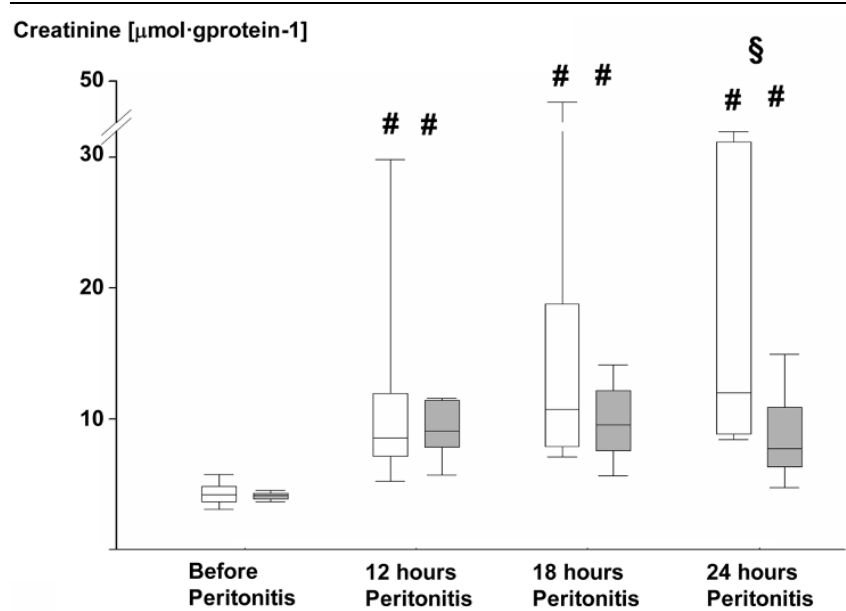

Blood creatinine levels in the control and AVP animals. Control $=$ open whiskers; $n=12, n=11$ at 24 hours. Arginine vasopressin (AVP) animals $=$ grey whiskers; $\mathrm{n}=12$. Data are median (quartiles, range). $\# P<$ 0.05 within groups versus before peritonitis; $§ P<0.05$ between norepinephrine- and AVP-treated animals. 
Parameters of systemic NO and cytokine production in the control $(n=12, n=11$ at 24 hours of peritonitis) and AVP ( $n=12)$ groups

\begin{tabular}{|c|c|c|c|c|c|}
\hline & & Before peritonitis & 12 hours peritonitis & 18 hours peritonitis & 24 hours peritonitis \\
\hline \multirow[t]{2}{*}{ Exhaled NO (pmol/kg/min) } & Control & 6 (3 to 47 ) & $22(6 \text { to } 72)^{b}$ & $27(11 \text { to } 98)^{b}$ & $15(14 \text { to } 141)^{b}$ \\
\hline & AVP & 5 (4 to 9 ) & $14(7 \text { to } 17)^{b}$ & $12(9 \text { to } 16)^{b}$ & $8(6 \text { to } 10)^{a}$ \\
\hline \multirow[t]{2}{*}{ Arterial $\mathrm{NO}_{3}{ }^{-}+\mathrm{NO}_{2}-\left(\mu \mathrm{mol} / \mathrm{g}_{\text {protein }}\right)$} & Control & $0.5(0.4$ to 1.6$)$ & $1.5(0.6 \text { to } 2.1)^{b}$ & $1.8(0.9 \text { to } 2.6)^{b}$ & $1.8(1.3 \text { to } 2.7)^{b}$ \\
\hline & AVP & 1.0 (0.6 to 1.3$)$ & $1.4(1.0 \text { to } 2.2)^{b}$ & $1.3(1.0 \text { to } 2.4)^{b}$ & $1.2(1.0 \text { to } 2.3)^{b}$ \\
\hline \multirow[t]{2}{*}{ Tumor necrosis factor- $\alpha\left(\mu \mathrm{mol} / \mathrm{g}_{\text {protein }}\right)$} & Control & 3 (2 to 3 ) & $10(8 \text { to } 16)^{b}$ & $20\left(^{12} \text { to } 25\right)^{b}$ & $27(15 \text { to } 55)^{b}$ \\
\hline & AVP & 2 (2 to 3 ) & $8(7 \text { to } 11)^{b}$ & $14(12 \text { to } 19)^{b}$ & $18(15 \text { to } 29)^{b}$ \\
\hline \multirow[t]{2}{*}{ Interleukin $6\left(\mu \mathrm{mol} / \mathrm{g}_{\text {protein }}\right)$} & Control & $1(1$ to 1$)$ & $125(56 \text { to } 286)^{b}$ & $549(252 \text { to } 1624)^{b}$ & $753(559 \text { to } 3443)^{b}$ \\
\hline & AVP & 1 (0 to 3$)$ & $83(51 \text { to } 150)^{b}$ & $216(119 \text { to } 365)^{a, b}$ & $354(140 \text { to } 677)^{a, b}$ \\
\hline
\end{tabular}

All data are median (quartiles). a $P<0.05$ between norepinephrine- and AVP-treated animals; ${ }^{\mathrm{b}} P<0.05$ within groups versus before peritonitis. AVP = arginine vasopressin; NO $=$ nitric oxide.

\section{Limitations of the study}

Mean blood pressure was significantly lower in the control group during the last six hours of the experiment due to the resuscitation protocol imposing a maximum noradrenaline infusion rate at heart rates of 160 beats/min or higher. Hence, any beneficial effect of AVP on organ function and/or damage could be referred to a higher perfusion pressure [53]. We think, however, that the lower blood pressure was unlikely to induce visceral organ ischemia: one control animal only became hypotensive with a mean blood pressure below the range reported to be associated with unchanged parameters of visceral organ perfusion and function in patients with septic shock [54,55]. Moreover, organ blood flow and $\mathrm{O}_{2}$ delivery was always well maintained and portal drained viscera $\mathrm{O}_{2}$ extraction, hepatic $\mathrm{O}_{2}$ uptake, regional venous $\mathrm{O}_{2}$ saturation, and lactate/pyruvate ratios were identical.

We used hydroxyethyl-starch for fluid resuscitation, because in swine this colloid caused less pulmonary dysfunction than Ringer's lactate [56] and attenuated capillary leakage [57]. Although we cannot definitely exclude that a hydroxyethylstarch overload contributed at least in part to the kidney dysfunction [58], this issue most likely did not assume any importance for the difference between the AVP and control animals: both groups received identical colloid resuscitation.

Finally, we investigated young and otherwise healthy pigs during the first 24 hours of sepsis, which precludes any conclusion on the safety of AVP infusion with respect to organ injury during prolonged administration and/or with underlying ischemic heart disease, congestive heart failure, or peripheral vascular disease.

\section{Conclusions}

In our clinically relevant model of fecal peritonitis-induced septic shock, low-dose AVP infusion supplemented with noradrenaline proved to be safe with respect to myocardial and visceral organ function and tissue integrity. Nevertheless, as we observed a reduced $\mathrm{dp} / \mathrm{dt}_{\max }$ in young animals without underlying heart disease, the use of AVP should be cautioned in patients with heart failure and/or cardiac ischemia, such as in the recent VASST [27]. It remains to be elucidated whether the attenuated inflammatory response and improved energy metabolism during AVP was due to the treatment per se and/ or to the reduced noradrenaline requirements needed to achieve the hemodynamic targets.

\section{Key messages}

- Low-dose AVP appears to be safe with respect to myocardial function and heart injury and even attenuates kidney and liver dysfunction and tissue damage during well-resuscitated porcine septic shock.

- An increased aerobic glucose oxidation and reduced hyperlactatemia suggests improved cellular energy metabolism, which coincides with less severe systemic inflammation.

- It remains to be elucidated whether this is due to the treatment per se and/or to the decreased exogenous catecholamine requirements.

\section{Competing interests}

$\mathrm{RL}$ is a full-time salaried employee of Ferring Research Institute Inc., San Diego, CA, USA. PA, PR, and EC received a research grant from Ferring Research Institute Inc., San Diego, CA, USA. PR and PA received consultant fees from Ferring Pharmaceutical A/S, København, Denmark, for help with designing preclinical experiments. The other authors declare that they have no competing interests.

\section{Authors' contributions}

PA, RL, PR, and EC played a pivotal role in planning and designing the experimental protocol. FS, MG, and FP carried 
out the anesthesia, surgical instrumentation as well as the online data collection. RG, BH, and MG were responsible for the data analysis. AS and PM provided the histomorphology and immunohistochemistry findings and the analysis of these data. JV and UW were responsible for the isotope data acquisition, analysis, and interpretation. MG, $\mathrm{PR}$, and $\mathrm{BH}$ wrote the manuscript.

\section{Acknowledgements}

Supported by Ferring Pharmaceuticals A/S, København, Denmark, and Ferring Research Institute Inc., San Diego, CA. The authors are indebted to Andrea Söll, Ingrid Eble, Tanja Schulz, Marina Fink, Rosy Engelhardt, Claus Vorwalter, and Wolfgang Siegler for their skillful assistance. Arginine vasopressin was provided by the Ferring Research Institute Inc., San Diego, CA.

\section{References}

1. Delmas A, Leone M, Rousseau S, Albanèse J, Martin C: Clinical review: Vasopressin and terlipressin in septic shock patients. Crit Care 2005, 9:212-222.

2. Dünser MW, Hasibeder WR: Vasopressin in vasodilatory shock: ensure organ blood flow, but take care of the heart! Crit Care 2006, 10:172.

3. Bracht $\mathrm{H}$, Asfar $\mathrm{P}$, Radermacher $\mathrm{P}$, Calzia $\mathrm{E}$ : Vasopressin in vasodilatory shock: hemodynamic stabilization at the cost of the liver and the kidney? Crit Care 2007, 11:178.

4. Hauser B, Asfar P, Calzia E, Laporte R, Georgieff M, Radermacher $P$ : Vasopressin in vasodilatory shock: is the heart in danger? Crit Care 2008, 12:132.

5. Luckner G, Hasibeder WR, Dünser MW: Vasopressor stays vasopressor and inotrope stays inotrope! Crit Care 2008, 12:415.

6. Martikainen TJ, Tenhunen JJ, Uusaro A, Ruokonen E: The effects of vasopressin on systemic and splanchnic hemodynamics and metabolism in endotoxin shock. Anesth Analg 2003, 97:1756-1763.

7. Guzman JA, Rosado AE, Kruse JA: Vasopressin vs norepinephrine in endotoxic shock: systemic, renal, and splanchnic hemodynamic and oxygen transport effects. J Appl Physiol 2003, 95:803-809.

8. Sun Q, Dimopoulos G, Nguyen DN, Tu Z, Nagy N, Hoang AD, Rogiers $\mathrm{P}$, De Backer $D$, Vincent JL: Low-dose vasopressin in the treatment of septic shock in sheep. Am J Respir Crit Care Med 2003, 168:481-486.

9. Levy B, Vallée C, Lauzier F, Plante GE, Mansart A, Mallie JP, Lesur $\mathrm{O}$ : Comparative effects of vasopressin, norepinephrine, and Lcanavanine, a selective inhibitor of inducible nitric oxide synthase, in endotoxic shock. Am J Physiol Heart Circ Physiol 2004, 287:H209-H215.

10. Malay MB, Ashton JL, DahlK Savage EB, Burchell SA, Ashton RC Jr, Sciacca RR, Oliver JA, Landry DW: Hetergeneity of the vasoconstrictor effect of vasopressin in septic shock. Crit Care Med 2004, 32:1327-1331.

11. Albert M, Losser MR, Hayon D, Faivre V, Payen D: Systemic and renal macro- and microcirculatory responses to arginine vasopressin in endotoxic rabbits. Crit Care Med 2004, 32:1891-1898

12. Westphal $M$, Freise $H$, Kehrel BE, Bone $H G$, Van Aken $H$, Sielenkämper AW: Arginine vasopressin compromises gut mucosal microcirculation in septic rats. Crit Care Med 2004, 32:194-200.

13. Di Giantomasso D, Morimatsu H, Bellomo R, May CN: Effect of low-dose vasopressin infusion on vital organ blood flow in the conscious normal and septic sheep. Anaesth Intensive Care 2006, 34:427-433

14. Knotzer $\mathrm{H}$, Maier S, Dünser MW, Hasibeder WR, Hausdorfer $\mathrm{H}$, Brandner J, Torgersen C, Ulmer H, Friesenecker B, lannetti C, Pajk $\mathrm{W}$ : Arginine vasopressin does not alter mucosal tissue oxygen tension and oxygen supply in an acute endotoxemic pig model. Intensive Care Med 2006, 32:170-174.
15. Hiltebrand LB, Krejci V, Jakob SM, Takala J, Sigurdsson GH: Effects of vasopressin on microcirculatory blood flow in the gastrointestinal tract in anesthetized pigs in septic shock. Anesthesiology 2007, 106:1156-1167.

16. Krejci V, Hiltebrand LB, Jakob SM, Takala J, Sigurdsson GH: Vasopressin in septic shock: effects on pancreatic, renal, and hepatic blood flow. Crit Care 2007, 11:R129.

17. Kopel T, Losser MR, Faivre V, Payen D: Systemic and hepatosplanchnic macro- and microcirculatory dose response to arginine vasopressin in endotoxic rabbits. Intensive Care Med 2008, 34:1313-1320.

18. Müller S, How OJ, Hermansen SE, Stenberg TA, Sager G, Myrmel $\mathrm{T}$ : Vasopressin impairs brain, heart and kidney perfusion: an experimental study in pigs after transient myocardial ischemia. Crit Care 2008, 12:R20.

19. Rehberg S, Ertmer C, Köhler G, Spiegel HU, Morelli A, Lange M, Moll K, Schlack K, Van Aken H, Su F, Vincent JL, Westphal M: Role of arginine vasopressin and terlipressin as first-line vasopressor agents in fulminant ovine septic shock. Intensive Care Med 2009, 35:1286-1296.

20. Dünser MW, Mayr AJ, Ulmer H, Knotzer H, Sumann G, Pajk W, Friesenecker B, Hasibeder WR: Arginine vasopressin in advanced vasodilatory shock: a prospective, randomized, controlled study. Circulation 2003, 107:2313-2319.

21. Klinzing S, Simon M, Reinhart K, Bredle DL, Meier-Hellmann A: High-dose vasopressin is not superior to norepinephrine in septic shock. Crit Care Med 2003, 31:2646-2650.

22. Lauzier F, Lévy B, Lamarre P, Lesur O: Vasopressin or norepinephrine in early hyperdynamic septic shock: a randomized clinical trial. Intensive Care Med 2006, 32:1782-1789.

23. Wilson MF, Brackett DJ, Archer LT, Hinshaw LB: Mechanisms of impaired cardiac function by vasopressin. Ann Surg 1980, 191:494-500.

24. Ouattara $A$, Landi $M$, Le Manach $Y$, Lecomte $P$, Leguen $M$, Boccara $G$, Coriat $P$, Riou B: Comparative cardiac effects of terlipressin, vasopressin, and norepinephrine on an isolated perfused rabbit heart. Anesthesiology 2005, 102:85-92.

25. Faivre V, Kaskos $\mathrm{H}$, Callebert J, Losser MR, Milliez $\mathrm{P}$, Bonnin $\mathrm{P}$, Payen D, Mebazaa A: Cardiac and renal effects of levosimendan, arginine vasopressin, and norepinephrine in lipopolysaccharide-treated rabbits. Anesthesiology 2005, 103:514-521.

26. Graf BM, Fischer B, Stowe DF, Bosnjak ZJ, Martin EO: Synthetic 8-ornithine vasopressin, a clinically used vasoconstrictor, causes cardiac effects mainly via changes in coronary flow. Acta Anaesthesiol Scand 1997, 41:414-421.

27. Russel JA, Walley KR, Singer J, Gordon AC, Hébert PC, Cooper DJ, Holmes CL, Mehta S, Granton JT, Storms MM, Cook DJ, Presneill JJ, Ayers D, VASST Investigators: Vasopressin versus norepinephrine infusion in patients with septic shock. N Engl J Med 2008, 358:877-887.

28. Barth E, Bassi G, Maybauer DM, Simon F, Gröger M, Oter S, Speit G, Nguyen CD, Hasel C, Möller P, Wachter U, Vogt JA, Matejovic $M$, Radermacher $P$, Calzia E: Effects of ventilation with $100 \%$ oxygen during early hyperdynamic porcine fecal peritonitis. Crit Care Med 2008, 36:495-503.

29. Russell JA: Vasopressin in septic shock. Crit Care Med 2007, 35:S609-615.

30. Rona G: Catecholamine cardiotoxycity. J Mol Cell Cardiol 1985, 17:291-306.

31. Movahed A, Reeves WC, Mehta PM, Gilliland MG, Mozingo SL, Jolly SR: Norepinephrine-induced left ventricular dysfunction in anesthetized and conscious, sedated dogs. Int J Cardiol 1994, 45:23-33.

32. Korvald C, Elvenes OP, Myrmel T: Myocardial substrate metabolism influences left ventricular energetics in vivo. Am J Phys iol Heart Circ Physiol 2000, 278:H1345-H1351.

33. Asfar P, Hauser B, Iványi Z, Ehrmann U, Kick J, Albicini M, Vogt J, Wachter U, Brückner UB, Radermacher P, Bracht H: Low-dose terlipressin during long-term hyperdynamic porcine endotoxemia: effects on hepatosplanchnic perfusion, oxygen exchange, and metabolism. Crit Care Med 2005, 33:373-380.

34. Chagnon F, Vaidya VS, Plante GE, Bonventre JV, Bernard A Guindi C, Lesur O: Modulation of aquaporin-2/vasopressin2 receptor kidney expression and tubular injury after endotoxin (lipopolysaccharide) challenge. Crit Care Med 2008, 36:3054-3061. 
35. Vernersson E, Ahlgren I, Aronsen KF: Effects of lysine-vasopressin treatment on renal function in burned pigs. Scand $J$ Plast Reconstr 1983, 17:25-31.

36. Patel BM, Chittock DR, Russell JA, Walley KR: Beneficial effects of short-term vasopressin infusion during severe septic shock. Anesthesiology 2002, 96:576-582.

37. Wendt $\mathrm{M}, \mathrm{Waldmann} \mathrm{KH}$, Bickhardt $\mathrm{K}$ : [Comparative studies of the clearance of inulin and creatinine in swine]. Zentralb/ Veterinärmed A 1990, 37:752-759.

38. Treschan TA, Peters J: The vasopressin system: physiology and clinical strategies. Anesthesiology 2006, 105:599-612.

39. Conrad KP, Gellai M, North WG, Valtin H: Influence of oxytocin on renal hemodynamics and eletrolyte and water excretion. Am J Physiol 1986, 251:F290-F296.

40. Dixey JJ, Willimas TD, Lightman SL, Lant AF, Brewerton DA: The effect of indomethacin on the renal response to arginine vasopressin in man. Clin Sci 1986, 70:409-416.

41. Gibson KJ, Lumbers ER: The roles of arginine vasopressin in fetal sodium balance and as a mediator of the effects of fetal 'stress'. J Dev Physiol 1993, 19:125-136.

42. Krayacich J, Kline RL, Mercer PF: Supersensititivy to norepinephrine in chronically denervated kidneys: evidence for a postsynaptic effect. Can J Physiol Pharmacol 1987, 65:2219-2224.

43. Lang CC, Rahman AR, Balfour DJ, Struthers AD: Effect of noradrenaline onr enal sodium and water handling in euhydrated and overhydrated man. Clin Sci 1993, 85:487-494.

44. Boyd JH, Holmes CL, Wang Y, Roberts H, Walley KR: Vasopressin decreases sepsis-induced pulmonary inflammation through the V2R. Resuscitation 2008, 79:325-331.

45. Moreau R, Barrière $E$, Tazi KA, Lardeux $B$, Dargère $D$, Urbanowicz W, Poirel O, Chauvelot-Moachon L, Guimont MC, Bernuau D, Lebrec D: Terlipressin inhibits in vivo aortic iNOS expression induced by lipopolysaccharide in rats with biliary cirrhosis. Hepatology 2002, 36:1070-1078.

46. Aninat $C$, Seguin $P$, Descheemaeker PN, Morel F, Malledant $Y$, Guillouzo A: Catecholamines induce an inflammatory response in human hepatocytes. Crit Care Med 2008, 36:848-854.

47. Bergmann M, Gornikiewicz A, Tamandl D, Exner R, Roth E, Függer $\mathrm{R}$, Götzinger $\mathrm{P}$, Sautner T: Continuous therapeutic epinephrine but not norepinephrine prolongs splanchnic IL- 6 production in porcine endotoxic shock. Shock 2003, 20:575-581.

48. Flierl MA, Rittirsch D, Nadeau BA, Chen AJ, Sarma JV, Zetoune FS, McGuire SR, List RP, Day DE, Hoesel LM, Gao H, Van Rooijen N, Huber-Lang MS, Neubig RR, Ward PA: Phagocyte-derived catecholamines enhance acute inflammatory injury. Nature 2007, 449:721-725.

49. Leverve $X M$ : Mitochondrial function and substrate availability. Crit Care Med. 2007, 35(9 Suppl):S454-S460.

50. Barth E, Albuszies G, Baumgart K, Matejovic M, Wachter U, Vogt J, Radermacher P, Calzia E: Glucose metabolism and catecholamines. Crit Care Med 2007:S508-S518.

51. Regueria T, Bänziger B, Djafarzadeh S, Brandt S, Gorrasi J, Takala J, Lepper PM, Jakob SM: Norepinephrine to increase blood pressure in endotoxemic pigs is associated with improved hepatic mitochondrial respiration. Crit Care 2008, 12:R88.

52. Singer M: Catecholamine treatment for shock - equally good or bad? Lancet 2007, 370:636-637.

53. Bersten $A D$, Holt AW: Vasoactive drugs and the importance of renal perfusion pressure. New Horiz 1995, 3:650-661.

54. LeDoux D, Astiz ME, Carpati CM, Rackow EC: Effects of perfusion pressure on tissue perfusion in septic shock. Crit Care Med 2000, 28:2729-2732.

55. Bourgoin A, Leone M, Delmas A, Garnier F, Albanèse J, Martin C: Increasing mean arterial pressure in patients with septic shock: effects on oxygen variables and renal function. Crit Care Med 2005, 33:780-786.

56. Margarido CB, Margarido NF, Otsuki DA, Fantoni DT, Marumo CK, Kitahara FR, Magalhães AA, Pasqualucci CA, Auler JO: Pulmonary function is better preserved in pigs when acute normovolemic hemodilution is achieved with hydroxyethyl starch versus lactated Ringer's solution. Shock 2007, 27:390-396.

57. Marx G, Pedder S, Smith L, Swaraj S, Grime S, Stockdale H, Leuwer M: Attenuation of capillary leakage by hydroxyethyl starch $(130 / 0.42)$ in a porcine model of septic shock. Crit Care Med 2006, 34:3005-3010.

58. Hüter L, Simon TP, Weinmann L, Schuerholz T, Reinhart $K$, Wolf G, Amann KU, Marx G: Hydroxyethylstarch impairs renal func- tion and induces interstitial proliferation, macrophage infiltration and tubular damage in an isolated renal perfusion model. Crit Care 2009, 13:R23. 